\title{
Informal Economy In Albania - Its Costs in the Country Development
}

\author{
Dr. Hysen Muceku \\ Prof. Assoc. Dr. Altin Muça \\ hysen_muceku@hotmail.com, amuca@besa.org.al
}

Doi:10.5901/mjss.2014.v5n9p642

\begin{abstract}
The informal economy is quite a controversial term and difficult to define precisely, but generally it summarizes in itself all unregistered aspects of economic and commercial activity in legal and fiscal system, that basically tent to avoid taxes and fees, the system of social security and health contributions, the mandatory norms of product safety, of their reliability as well as their business social responsibility. The loss that the state and society have suffered from the informal economy is large enough, this seen in different ways. Non-collection of taxes and contributions automatically led to an impoverishment of the state budget and lack of investment in public services. A social responsibility has continuously accompanied and threatened the government performance, and it is especially more vulnerable to the level of pensions and salaries, as well as in the quality of public services and investments. Actually, the debate on the informal economy, on the means and ways to "dominate" such economy, being unable to finally reduce it, is in a critical stage, even in developed countries. According to official statistics, the informal economy fluctuates in levels 5-20 \% of GDP in different EU countries. Features of this "type" of economy is that it generally reaches the highest values in developing countries, where economic and social development, culture and respect for the rule of law , are low. The level of informal economy in Albania (actually, according to official statistics accounts for about 33 percent of GDP1) needs to be treated as a real threat to the economic stability of our country. Legal stability (recently there has been a frequent change of laws) is considered Important in reducing the informal economy. The fight against informality requires an integrated legislative package of measures aiming at the improvement, control and the rigorous implementation of the legislation requirements, the promotion of initiatives for a self- breakaway to from informal economy and creation of tangible opportunities to integrate liberated capital in priority development programs, in order not to repeat the negative phenomena that are still holding hostage the Albanian economy.
\end{abstract}

Keywords: Informality, tax evasion, fiscal policy, unlawful activities, formalization of the economy.

\section{Theoretical Concept of the Informal Economy}

The term "informal economy" refers to all "unobserved" economic activities, carried out by employees and economic entities, which aim the avoidance of tax or operation contrary to the laws, rules and administrative procedures applied.

This definition does not cover all types of tax avoidance and illegal income received since it refers to the avoidance related to the production of goods and services and does not reflect fiscal evasion related to capital profit. The definition should include the illegal criminal activities such as trafficking and smuggling, as well as tax-free household and agricultural activities (household production) serving as sustenance.

Various studies and current practice argue that the informal economy is not a temporary phenomenon, but it is considered an inevitable phenomenon for those countries that fail to distribute effectively the income and capital, therefore, if economic growth is not accompanied by increase of the employment level and improved income distribution, the informality cannot be reduced, regardless of the development level of the country.

It is important to answer the following questions:

- To what degree does the country "poverty" level affect the informal economy?

- How to measure the informal economy if it is not documented / recorded?

- Who are the directly affected stakeholders and what is the government impact in reducing or curbing this phenomenon?

The informal economy is generally characterized by:

- Lower demand in terms of capital and personal qualifications for entry into the market;

\footnotetext{
${ }^{1}$ According to official data from the OECD, the level of informal economy in developing countries is about $41 \%$, in transition countries is about $38 \%$ and in those that are OECD members is about $18 \%$.
} 
- Skills acquired outside the formal education;

- Intensive production methods derived from the labor force and inappropriate technology;

- Operation out of economies of scale, but with lower cost.

\subsection{Measuring the degree (level) of the informal economy}

Assessing the size of such economy is difficult, because it is related with measuring the phenomena that are unregistered and without any database. Because getting this information has high costs, the government aims to achieve a balance between the necessary information and costs of providing this information in order to be cost effective.

Several methods are used to measure the informality, among which the most important are the following:

\subsection{Indirect method (indirect)}

The majority of the countries, including Albania, rely on indirect methods for measuring the informal economy. Depending on the workforce, the main goal is to segment the employees that are paid according to the census or surveys, in order to determine the number of employees that belong to the informal sector and those that belong to the formal one. These data serve as the basis for the statistics, but not to identify informal enterprises, as such information is very difficult to obtain from the polls. The purpose of measuring the economy or the informal sector is its presentation in terms of numerical value in relation to GDP and the country revenue, in order to become comparable with previous periods or other countries. These techniques consist in comparing the added value by sectors or industries in the state budget to the added value in the formal sector of the industry.

\section{The Informal Economy in Albania and the Factors Affecting Its Growth}

The informal economy is considered an inevitable disease and as such, the focus of every government is not its elimination, but its reduction in appropriate levels not to hinder the development of the country.

The informal economy in Albania was first appeared during the transition phase of the centralized economy to the market economy, because in this period, the development of the regulatory, legal, institutional and fiscal framework remained far behind in comparison with the development of free enterprise, according to official statistics in Albania the informal economy currently accounts for about 33 percent of GDP.2

Given the features of Albania, the size of the current informal economy poses a serious threat to the fair competition, which is the main tool for development. Businesses that operate in the "gray" zone of the economic sector tend to avoid tax obligations (performing evasion) in order to reduce the costs of paying taxes and insurance. In these conditions they gain a considerable advantage compared with those businesses that conduct their activities according to the rules and regulations in power. Unfair competition has not only led to the bankruptcy of businesses that operate according to the rules, but has encouraged "leak" or "transfer" of businesses from the formal to the informal economy.

Some key factors that influenced the growth of this sector in Albania are as follow:

$>$ The relatively large number of legal and administrative rules: the greater the number of rules, such as business registration, requirements for the license and permit for the exercise of activity, limitations of labor market, market entry barriers, etc., the more informal economy is stimulated.

$>$ Lack of trust in public institutions / state corruption: here we can mention the corruption in the judicial system, unclear legislation and bureaucracy.

$>$ Restricted (limited) access in the formal property system: it refers to the absence of clarity about property rights or property title and the inability to collateralize these assets becoming an entry barrier for firms and individuals in financial institutions as credit lines, insurance companies and financial and capital markets.

$>$ Decrease of the individuals' awareness, expressed as a reduction in loyalty to public institutions combined with the reduction of discipline in payment of fees and taxes.

$>$ Acceptance of illegal labor often approved or tolerated by the state.

If we refer to the nature of the informal economy in Albania it is noticed that, after the 1990 there has been a significant increase up to today's levels. This relates to the fact that during the period of the centralized economy, the private economic activity was forbidden by law.

${ }^{2}$ According to official data from the OECD, the level of informal economy in developing countries is about $41 \%$, in transition countries is about $38 \%$ and in those OECD members is about $18 \%$ 
Economic crisis of the '90-'92, very critical regarding problems of high unemployment, poverty and social insecurity, gave people a powerful impulse to respond creatively to their difficulties by becoming part of the informal economy.

The most disturbing problem of informality in Albania is mainly in the fields (tax and customs) related to different business activities, which, though being registered, they do not accurately declare annual turnover, profit, number of employees and real wages. Businesses that own the majority of economic activity have the greatest impact in this economy.

Another important factor regarding the informal economy is the structure of business and number of employees. According to studies conducted, it results that the largest enterprises in the Albanian private sector have the largest number of employees. The collapse of the communist system brought about the increase of the emigrants number, a phenomenon that in the short term had a significant impact on remittance growth, stabilization of macroeconomic indicators as well as on the increased investment, thus improving the welfare of individuals.

The negative effect of remittances is seen in the fact that they encouraged informality through the flow of "cash" out of the banking system channels, making it impossible to identify and measure their impact on the real economy.

So, the fierce market competition, the difficulties and entry barriers, as well as the lack of legal capital led many firms in this period to operate in the informal economy.

From the analysis of the main problems and those most influential in this sector during the transition period in Albania, it results as follows:

\subsection{Poverty}

Poverty is the result of economic, social, political and cultural factors, which affect each other, exacerbating and worsening further the situation.

Poverty is associated not only with insufficient income and consumption, but also with the inadequacy of health services, food, education services, lack of social relations, insecurity, and lack of poker and lack of reliability. A person is considered poor if the level of income or consumption drops under the necessary level to meet its basic needs. ${ }^{3}$

The private sector may reduce poverty by contributing to economic growth, creating new jobs and increasing incomes of poor people. It can also help the poor by providing a wide range of products and services with lower prices.

Poverty in Albania appears multidimensional in the following aspects:

- Low or very low income level;

- High vulnerability of disease and inability to access appropriate medical services;

- Illiteracy or low level of education;

- High level of exposure to risks and weak voice in governmental decision-making institutions.

According to various studies and statistics about $12.4 \%$ of Albanians are poor, while $1.2 \%$ of this category lives in extreme poverty. ${ }^{4}$ Consequently, the response of this layer of population to this phenomenon is the hidden employment. When people are unemployed and cannot generate enough money for their living, then they rely on alternative sources of informal economy.

\subsection{Unemployment}

The unemployment rate is the ratio of unemployed to the labor force. The labor force includes all persons employed and unemployed. Unemployment can be considered as one of the most difficult "diseases" (problems) today and is generally a result of the economic recession. The unemployment level in Albania remains still high.

Unemployment economic losses are estimated to be greater than the losses sustained by the society due to the inefficiency of monopolies or tariffs and quotas. In these conditions, the unemployment rate becomes a measure of a country's economic health. In situations of unemployment, the production gap takes negative values. The unemployment rate in Albania registered in the fourth quarter of 2013 results to be $13.5 \%$.

Unemployment rate in years

3Measuring inequality: World Bank 2011 
Source: Data from the Report of INSTAT on unemployment

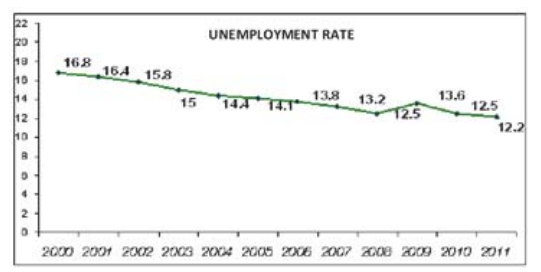

\subsection{Corruption}

Corruption is perceived as the most disturbing problem in Albanian society, because doing someone a favor, due to its non-monetary character and its role in the redistribution of income and power, is considered as more acceptable by the society. While bribery is perceived less acceptable, as seen as a mechanism that produces social inequality. Corruption hinders economic growth, destroys democracy, degrades society and destroys the chances of putting the rule of law.

In post-communist Albania, corruption is of clientelistic nature and is closely connected with the formation of political parties and redistribution of state property.

In Albania corruption is widespread, becoming an integral part of the institutional system. Individuals perceive that, in order to set in motion their rights practices, they should expect the abnormal bureaucracy imposed by the state administration employees. On the other hand, the key to put things in motion is the "promise" for a possible reward. But, corruption is widespread in lack of business declaring their real activities, making secret deals with fiscal administration officials.

\subsection{Informality in the tax system}

Since year 1997 Albania is making significant efforts to establish a system of taxes and fees according to EU member countries model (for the VAT, personal income tax and profit tax). Although positive steps have been taken in implementing a number of programs to improve the fiscal system and to reduce the informal sector, Albania still has an informal sector at a high level.

The situation inherited in this area is problematic. A considerable number of firms have developed for a long time economic activity out of the evidence and surveillance of fiscal authorities, i.e. in the informal sector of the economy or they have only partially declared their activity, hiding in this way a significant part of transactions performed and consequently the cash flow and corresponding profits.

Fiscal environment in which the fiscal administration operates has drastically changed in the last two decades. Although the tax base is expanding and the number of taxpayers is increased, at the same time it is increased the tax authorities work to educate taxpayers and tax administration. Also, during these years there have been significant changes in the techniques used for the assessment and collection of taxes using new technologies (IT) for the administration of taxes and fees. These improvements have created opportunities for improving the efficiency of tax administration.

Main fiscal factors that encourage informality in the Albanian economy are:

Non-declaration. Lack of economic information presentation related to the transactions carried out is considered a non-declaration. This is a widespread phenomenon in the economy. A part of businesses hide and don't declare the commercial operations they conduct effecting negatively the economy. Because of the non-declarations, the tax inspectors fail to make a fair assessment of real business situation. Many businesses choose not to declare the number of employees in their company, the different purchases and sales they make, or the selling prices of their products and services.

Failure to keep a regular tax database. Another problematic factor is also the failure of keeping regular tax documentation. This is evident when we refer to the type of invoices issued by businesses, lack of cash registers usage by the businesses, non declaration of prices and cash transactions in the economy.

Setting the wages below the reference level. One of the main problems of the albanian businesses is the declaration of the payroll expenses. The trend over the years has been to declare lower wages in order to reduce as much as possible the tax obligations as well as social security and health insurances. To reduce this level of informality, the government has occasionally set reference wages (the minimum and maximum) in order to approach business statements as much to the reality, but, despite the measures taken, still these businesses find room for fiscal evasion. 
Tax evasion. Tax evasion is a disturbing problem, not only for transition countries like Albania, but also for countries that have a developed fiscal system. The presence of this phenomenon and the level of its extension lead to a reduction in tax revenue. Concealment of tax obligations, through the submission of false documents, false statements or unreal information, which consideration leads to inaccurate calculation of the amount of tax, creates tax evasion. This is the definition by law for this type of law violation, considering it as the most serious violation for which the taxpayer might face not only severe administrative sanctions but even the relevant criminal sanctions.

A problem for Albania is that there are still no accurate statistics and standardized methods for determining tax evasion. There are no accurate reports of the responsible institutions for this phenomenon. Albanian businesses, experiencing a rapid growth, often are tempted to gain privileges/benefits via the deliberate tax evasion. The poor tax infrastructure, lack of human resources in this area has so far made it easy to carry out such informal activities.

According to the report "Doing Business 2009", in order to start a business in Albania there should be applied 6 startup procedures which require on average 8 days to be fulfilled. But, how much does it cost to start up a new business in Albania?

Based on the same studies, the results recorded in monetary value is of concern, since the average cost of setting up a business is $71.700 \mathrm{ALL}$ (approximately 700US\$) and apart that, there is enough lost time and suffering from a series of bureaucracies.

There are also required many forms and documents in the different steps of the registration process. Many entrepreneurs think that the theoretical process of registration and obtaining the license seems to be fast and cheap, but in practice it does not seem to be like that considering that they have to go through this process, deal with relevant institutions, try to obtain the licenses, sometimes have to pay informal fees, and all this makes the regulatory framework costly and problematic.

A significant impact on informality has had the exercise of different activities by unlicensed entities, as shown in the figure below, where about $10 \%$ of the total entities do not have a license.

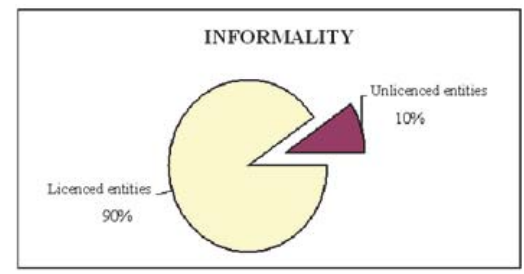

Source: Annual Report 2012 of Tax Administration

\subsection{Informality in the customs system}

Despite the advances made in this system, where so far have been taken a series of reforming steps, still the administrative barriers and especially the burden of customs procedures for business, remain a serious problem.

The main fiscal factors that encourage informality in the customs system are:

Lengthy and costly customs procedures. Lengthy and costly customs procedures as well as the unpredictable delays are not only serious obstacles for import and export, but also for foreign investment capital, especially in the manufacturing sector, which are of particularly importance in achieving the development objectives. Although, in recent years, according to the report "Doing Business" there have been positive developments in terms of reducing the customs processing time, which shows that the average clearance time during 2012 was approximately 1.9 days (14.8 hours) compared to 5.3 days in the past years.

The process of clearance, clearance cost, number of documents, and export and import time. Customs system has shown significant progress moving gradually from a system based almost entirely on paper records and documents in automated information systems.

But, still it is evident that, generally there are delays in the processing of information by the customs due to system faults, load on the network, uncompleted automated information system at all customs points, insufficient preparation of professional staff, etc. According to the report "Doing business", the cost of export is 725 US\$, cost of import 710 US\$, export documents number is 7 , while those of import 9, export time is 21 days, while import time 22 days, which rank Albania the 66th. Despite the progress, the Albanian customs service quality still needs to be improved in terms of reducing the number of necessary documents, making the import and export procedures faster and cheaper, in order to increase competitiveness.

Ethic Issues. There are identified issues of poor ethics of customs administration in relation to the business. These 
issues are made evident in several reports that are published and occasionally there are given concrete recommendations. The regulation on ethics has been very poor in formulating the rights and obligations of customs employees, as well as of the private entities in their dealings with the customs administration.

Transaction costs $=$ costs of customs procedures that are necessary and efficient + cost of customs procedures that are unnecessary and inefficient + costs of corruption. Transaction costs are especially increased due to customs procedures that are unnecessary and inefficient, and the costs of corruption.

Transparency of customs administration. Increased transparency of customs administration in relation with the business is essential in the fight against corruption and abusive application of customs legislation that favors evasion. The institution of customs administration continues to rank as the institution with the highest level of corruption.

\section{The Formalization of the Informal economy in Albania - A Multi-Dimensional Challenge}

Informality in Albania, as discussed above, appears in a multi-dimensional plan and is one of the most difficult reforms to be undertaken. There are many businesses that conduct their activities without being registered, although the necessary measures are taken to identify and register those businesses that operate illegally.

The main factors that develop a suitable ground for informality in Albania are: over-power, secret negotiations and subjective interpretation.

Over-power is one of the diseases that should be cured as soon as possible in the Albanian administration. Code of ethics should be recognized well and every employee should have clearly defined tasks. An individual who holds a senior post in the administration level should not be able to take arbitrary decisions.

Secret negotiations are another factor that develops informality in the Albanian economy. Fiscal employees have the opportunity to create "secret negotiations" with the control entities, distorting information and unfairly favoring some businesses. But, given the current law that requires the creation of electronic files, the opportunity for these "negotiations" reduces. Every taxpayer has the right to impartially, professionally, and ethically treat issues related to tax liabilities.

Subjective interpretation is one of the most controversial issues that can find solutions due to the application of NAS (National Accounting Standards)5. They clearly present how an event is made evident, how is it assessed and how will it be reflected in the financial statements. Recognition and correct implementation of national accounting standards, updated and in line with the international accounting standards and financial reporting (IAS / IFRS), will lead to a significant improvement of the overall quality and scope of financial reporting, by the private and public economically profitable entities. This will make possible the improvement of decision making, the management efficiency and will increase transparency and reduce the country's economic informality.

The efforts to reduce informality will require more work, time and financial support because this type of fight is multi-dimensional and complex. Government has taken measures to reform the tax administration and, what is most important, the support and goodwill of the business, are key tools to combat this phenomenon that threatens the very prospect of the Albanian economy. The government should undertake concrete and reliable actions to minimize the informal economy, coordinated with all market participants:

First: Identification of the real economic activity of market players. This activity should be controllable by state authorities (customs and tax);

Second: Legal collection of the tax obligations to be paid to the state budget. It should be in compliance to rules and regulations and not using inefficient administrative methods;

Third: Implementation of the law equally for all the market actors. This helps and encourages the country economic development in conditions of the fair competition.

The high degree of informality makes it difficult for the government to collect revenues for the budget, while the government itself should not allow informality.

So it looks like we are in a vicious circle. In fact, the way to reducing informality is not in the form of a vicious circle, but in the form of a classical spiral, the perimeter of which is ever decreases, approaching the peak. This means that economic agents' efforts coordinated fairly by the government will constantly reduce the informal sector. Existing problems in revenue collection raise the question: under what conditions the government's ambitious objectives can be realized in the near future? The main lesson from the practice of countries in transition is that: "Improving governance to achieve social objectives means to pass from an economy without infrastructure and misleading network of social protection in a formal economy that pays taxes, with small but efficient social protection networks". Anyway, many of these reforms cannot be successful without the reduction of corruption, bureaucratic inefficiency and of the other causes

514 SKK shpallur me Urdher te Ministrit te Financave nr.4292 date 15.06.2006. Implementimi i tyre 1 janar 2008. 
that create informal economy.

In this period, great efforts are being made to reduce the cash economy. Identification of cash that is transferred through formal channels affects the reduction of corruption and evasion and will undoubtedly result in the reduction of informality. Banks, small and medium businesses, and individuals are among the main actors that effect the reduction of cash transactions in the economy.

State institutions, such as state inspectorates, through inspections and enforcement of legal frameworks that regulate this activity, play an important role in reducing the informal labor market.

Increasing transparency. Transparent information is a prerequisite for business development. This information will not only assist in developing local business, but it will also help the foreign investors. Given the new law for the tax procedures, the businesses are compelled to make their statements electronically, on-line. Electronic on line payment of taxes, defined by law, will significantly facilitate taxpayers meet tax obligations, reducing contacts with the tax administration and reducing opportunities for corruption.

\subsection{Implementation strategy for the formalization of the economy}

Preparation of plans and strategies for the reform requires adequate data about problems, information on typologies, stakeholders and cost-benefit analysis. Formalizing, without a comprehensive reform, tends to encourage informality. Applicable rules should be easily understandable and clear to any economic actor, including more sophisticated businesses as well as small enterprises.

Having the necessary level of flexibility for possible amendments and improvements, any legal system should convey a certain level of predictability. Legal aspects should include key elements for the organizational forms to be developed over the allocation of capital, limited liability, the level of profits, transfer of shares and capital, etc.

The experience of OECD countries may serve as a positive experience for countries in transition, which indicates that there is no magic formula or a single solution to turn the informal economy into a formal one. Valuable recommendations to undertake various legal initiatives can be developed and implemented only through a process of discussion and a concrete action strategy for its implementation, involving all stakeholders in this process: government, public administration, civil society, private entrepreneurs, trade unions, etc.

The world economy is experiencing rapid changes, versatile transformations, above all it is showing rapid qualitative and multi-dimensional transformations that have their basis in the rapid development of technology and knowledge.

The existence of spatial divisions and concepts is being continuously adapted to overcome national borders against economic limits set by the regions and market areas. Governments have undertaken a series of specific reforms to fight corruption and informality creating agencies that regulate the ownership of illegal constructions, restore and compensate assets received, urban infrastructure development etc., but these agencies should be more effective in their work. On the other hand, there are undertaken initiatives for reforms to reduce corruption in tax policy and public procurement administration, as well as regarding the business registration procedures. The current environment requires facilitating the business climate, increased competition, the adoption of more accessible laws and rules, increasing opportunities and challenges to compete with other countries in the region and those of the EU.

Despite efforts, the legal system is still not friendly especially for small businesses. The majority of Albanians have substantial assets, mainly property and businesses. Meanwhile, these assets remain outside the legal system, unable to become an active part of investments and progress; they cannot be identified, located or are not legally presentable. Consequently they will be understated, not likely to be used freely, therefore economically unproductive. should:

For the development and implementation of the strategy in reducing the informal sector of the economy there

First: The existence of spatial divisions and concepts should be adapted more and more to overcome national borders and boundaries versus established economic regions and market areas.

Second: The main attention of the development policy is focused on those factors and elements that can yield quick results such as: rapid privatization of the albanian economy and development of banking sector. However, it should be noted that the infrastructure has left to some extent in limbo the strategic policy issues of business development such as education and training of human resources, which require a relatively long time to return on investment, but are essential directions of qualitative developments in achieving objectives of productivity and business competitiveness.

Third: While the speed of the previous stages of market liberalization reforms gave no opportunity for more detailed analysis, in terms of more potential sectors and products with competitive advantages, the attention should be focused on current opportunities of the Albanian economy for the integration in international markets (as agri-business and tourism). 


\section{Conclusions}

Applicable rules should be easily understandable and clear to every economic agent, from the most sophisticated businesses to the smallest entrepreneurs. Having the necessary level of flexibility for possible amendments and improvements, any legal system should convey a certain level of predictability.

Countries with more corruption have higher informal economy. Fighting corruption is perceived as strengthening and consolidation of state institutions, increasing political stability, productivity and law enforcement. The fight against corruption should also be seen as a growing civic consciousness and individual accountability, as well as strengthening and modernization of public administration to reduce the sector.

A very important problem is the competition, which should create equal opportunities for all. Free and fair competition leads to the reduction of arbitrariness, which is a widespread and stumbling phenomenon to the Albanian economy as a whole. Reduction of arbitrariness would bring growth and strengthening of activities, and reduction of bankruptcy possibility.

Countries with low taxes tend to have a lower level of informal economy. However, it should be noted that the tax breaks only stabilizes, but not necessarily reduces the informal economy, so there is room for adjustments in the tax system by making them simple and more logical to citizens and more applicable in terms of the Albanian economy.

"The fight against tax evasion" is a very broad and ambitious objective, where public expectations for real improvements will remain small as long as no practical steps will be taken to tackle the issue of any commodity, for any tax, and for every single problem. Since, the most interested party in fighting the tax evasion are the companies that pay regularly, but because of costs they are in an unfavorable position, they should necessarily be included in discussions for designing the strategies.

An important tool for reducing the informal economy is the fight against the cash economy. In order to reduce cash economy, the government needs primarily to create a fair competition environment and safe economic-legal one to use the alternative tools.

To reduce the informal labor market, it is needed a greater collaboration of relevant state institutions [SII (Social Insurance Institute), AIS (Albanian Institute of Statistics), GDT (General Directorate of Taxation), PHI (Public Health Institute)] to reconcile the data for the calculation and inclusion in the insurance scheme of the persons liable to pay contributions.

Legal stability is important for reducing the informal economy, because the recent years there have been frequent changes of laws. The fight against informality requires an integrated legislative package of measures with three major components: 1) improvement, control and rigorous implementation of the fiscal legislation requirements, 2) adoption of initiatives to cut out of the informal economy and 3) creation of tangible opportunities to integrate the liberated capital into priority development programs, not to repeat the negative phenomena that are still holding hostage the economy.

\section{References}

Feige E. 1989. The underground economies. Tax evasion and information distortion. Cambridge University Press.

Tamas k. Papp and Elod Takats, Tax rate cuts and tax Compliance-The Laffer Curve Rivisited, IMF Working Paper , January 2008. Jaime Guajardo, Bussiness Cycles in Small Developed Economies: The role of terms of trade and Foreign Interest Rate shocks, IMF Working Paper, April 2008.

OECD 2004. The informal Economy in Albania- Analysis and Policies Recommendations Howell H.Zee,Bristow John,Simard Dominique , Albania: Selected Issues in Tax Design, IMF, December 2004. European Economy, 2006 Economic and Fiscal Programmes of potential countries, by Directorate General for Economic and Financial Affairs, February 2007.

Ekonomia Informale si barrierë për një zhvillim të qëndrueshë" Prof. Asoc. Dr. Fatmir Mema, Dr. Zef Preçi

"Sektori jolegal ekonomik, një kërcënim dhe sfida mjaft serioze për aspiratat zhvillimore dhe integruese të vendeve në tranzicion" Rufi Osmani.

Development Alternatives, Inc, USAID, Albania Enterprise Development \& Export Market Services, June 2006. Garbis Iradian, Rapid Growth in Transition Economies : Panel Regression Approach, IMF Working Paper, July 2007.

ILO, Supporting workers in the IE: a Policy Framework, ILO, 2002

ILO, The Dilemma of the Informal Sector, International Labour Conference,

De Soto H., Mystery of Capital: Why Capitalism Triumphs in the West \& Fails Everywhere Else, 2000

Holzner, M. (2003), Measuring the informal economy, in: Gligorov, V., Christie, E., and Holzner, M. An Informal Discussion On the Informal Economy, paper presented at the wiiw-GDN Workshop on Enterprise Development, Informal Economy and Labour Markets, April 4-5, 2003, The Vienna Institute for International Economic Studies (wiiw).

INSTAT. Vjetor statistikor. Tiranë, 2011, 2012.

Banka e Shqipërisë Raporte statistikor- Dhjetor 2011, Dhjetor 2012.

OECD "The Informal Economy in Albania: Analysis and Policy Recommendations. 